Z. klin. Chem. u. klin. Biochem.

8. Jg., S. $480-482$, September 1970

\title{
The Rapid, Enzymatic Determination of Glucose in Hemolysates
}

\author{
By R. HAECKeL \\ Aus dem Institut für Klinische Chemie (Geschäftsf. Direktor: Prof. Dr. Dr. J. Büttner) der \\ Mediqinischen Hochscbule Hannover
}

(Eingegangen am 13. Mai 1970)

A modified procedure for the enzymatic determination of glucose in the hemolysate from $5-10 \mu l$ blood samples is described. The result was available 5-10 minutes after capillary puncture and the reliability was adequate, providing the samples contained no fructose.

Ein modifiziertes Verfahren zur enzymatischen Bestimmung von Glucose im Hämolysat von 5-10 $\mu l$ Blutproben wird beschrieben. Das Ergebnis wurde 5-10 Min. nach der kapillaren Blutentnahme ethalten. Die Zuverlässigkeit der Analysen war ausreichend, solange die Proben keine Fructose enthielten.

Recently STORK and SCHMIDT (1) described an enzymatic method for the rapid determination of glucose in small blood samples. They used the well-known hexokinase reaction coupled with the glucose-6-phosphate dehydrogenase reaction to oxidize glucose to 6-phosphogluconate in the presence of NADP. Since the hemolyzed blood samples were introduced directly into the assay without prior precipitation of proteins, the whole procedure lasted only a few minutes from the capillary puncture until the result was available.

This method seemed to be valid for the handling of a hyper- or hypoglycaemic coma when single and rapid determinations are needed. The reliability of the method was therefore studied.

\section{Methods}

The following modification of the procedure recently described by STORK and SCHMidT (1) was used:

$\begin{array}{lc}\text { Solution } 1 & 2.0 \mathrm{ml} \\ \text { Solution 2 } & 0.1 \mathrm{ml} \\ \text { Sample (blood, serum) } & 0.01 \mathrm{ml} \\ \text { Mix and tecord extinction E } & (\mathrm{O} . \mathrm{D} .) \text { at } 366 \mathrm{~nm} \\ \text { Enzyme suspension } & 0.01 \mathrm{ml}\end{array}$

Read $\Delta \mathrm{E}$ at the end-point of the reaction.

Calculation

$(4 \mathrm{E}-0.005) \times 1157=\mathrm{mg} / 100 \mathrm{~m} /$ glucose.

At values over $400 \mathrm{mg} / 100 \mathrm{~m} /$ the hemolysate was diluted $1+1$.

Solution 1

1. $2.0 \mathrm{~m} l 0.012 \mathrm{M}$ NADP

2. $2.0 \mathrm{~m} / 0.016 \mathrm{M}$ ATP

3. $5.0 \mathrm{ml} 0.3 \mathrm{M}$ triethanolamine $(\mathrm{pH} 7.5)$ and $0.004 \mathrm{M} \mathrm{MgSO}$

(1.-3. were taken from Boehringer test combination TC-X-1).

4. $5.0 \mathrm{ml} 0.04 \mathrm{M} \mathrm{MgCl}_{2}$

5. $2.0 \mathrm{ml} 12.5 \%$ Triton X 100 (Serva, Heidelberg)

6. $84 \mathrm{~m} /$ dist. water.

This mixture was kept at $4^{\circ}$ and used for 1 week.

Solution 2

$3 \mathrm{~g}$ N-ethylmaleinimide (Fluka AG, Buchs, Switzerland) in $100 \mathrm{~m} l$ dist. water. This solution must be filtered after its preparation and is stable for several weeks if kept at $4^{\circ}$.

\section{Enzyme suspension}

$1 \mathrm{mg} / \mathrm{m} l$ hexokinase and $2 \mathrm{mg} / \mathrm{ml}$ glucose-6-phosphate dehydrogenase (Boehringer test combination TC-X-I).

The capillary blood was aspirated in 5 or $10 \mu l$ disposable micropipets. (DADE Reagents Itd., Miami, USA.) The small sample volume required an exact handling of the micropipets. Labtrol and Monitrol I were obtained from DADE Reagents Ltd., Miami USA.

Parallel determinations were performed with the Boehringer test combination TC-X-I in an Eppendorf automat 5030. We followed the procedure (Nr. AV $208 \mathrm{MV}$ ) distributed by Eppendorf Gerätebau GmbH., Hamburg. $50 \mu l$ blood samples were deproteinized with $0.3 \mathrm{~N}$ perchloric acid using an Eppendorf dilutor 5031. After centrifugation the supernatant was put into the automat. This procedure yielded linearity up to concentrations of $500 \mathrm{mg} / 100 \mathrm{ml}$. The coefficients of variation from different series of glucose determinations in Monitrol I and Labtrol samples ate listed in Table 1. The interaction coefficient of this procedure was 0.0081 ( $s=0.0026, \mathrm{n}=10$ ) as calculated according to HJELM (2).

Tab. 1

Precision of glucose determinations in various control sera on different days

\begin{tabular}{lcccc}
\hline \multicolumn{1}{c}{ Serum } & $\mathrm{n}$ & $\begin{array}{c}\overline{\mathbf{x}} \\
(\mathrm{mg} / 100 \mathrm{ml})\end{array}$ & $\pm \mathrm{s}$ & $\mathrm{cv}$ \\
\hline Monitrol I & 12 & 84.2 & 1.3 & 1.6 \\
Monitrol I & 22 & 83.3 & 1.1 & 1.3 \\
Labtrol & 23 & 86.3 & 1.8 & 2.1 \\
Labtrol & 12 & 99.4 & 1.2 & 1.2 \\
Labtrol & 11 & 101.1 & 1.5 & 1.5 \\
Labtrol & 19 & 89.0 & 1.5 & 1.7 \\
Labtrol & 15 & 98.6 & 1.2 & 1.2 \\
Labtrol & 13 & 97.4 & 1.5 & 1.6 \\
Labtrol & 19 & 101.3 & 1.8 & 1.8 \\
\hline
\end{tabular}

\section{Results and Discussion}

The NADP reduction usually obtained, using the procedure of STORK and SCHMIDT, is recorded in Figure 1. From the calculated data it can be seen that the difference in optical density $(\Delta \mathrm{E})$ should be read after $5 \mathrm{~min}$. An endogenous reaction continued to reduce the NADP after all the glucose had been converted to 6-phosphogluconate.

50 determinations of blood glucose from different individuals were recorded and the 5 minutes $\Delta \mathrm{E}$ value, the endogenous reaction rate and the true $\Delta \mathrm{E}$ value (that means the 10 minutes $\Delta \mathrm{E}$ value minus the endo- . genous reaction rate) calculated as shown in Figure 1. 


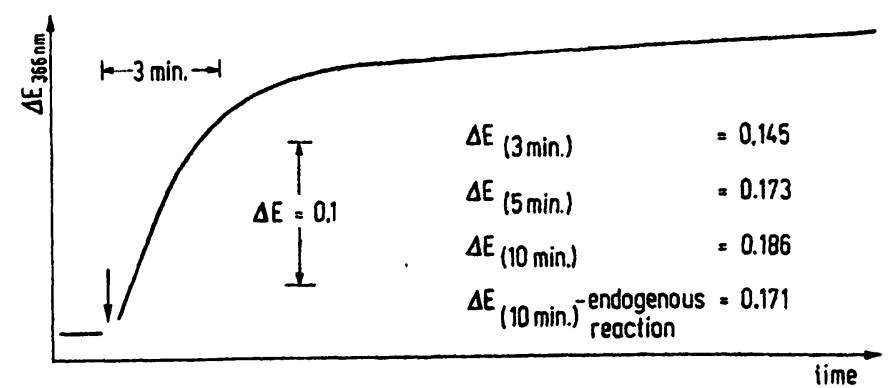

Fig. 1

Record of the NADP reduction rate under the assay conditions at $366 \mathrm{~nm}$ in the absence of N-ethylmaleinimide

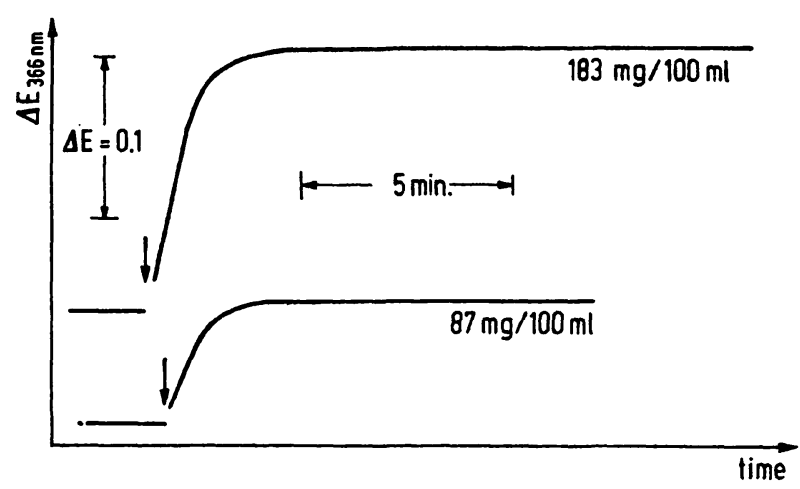

Fig. 2

Record of the NADP reduction in the hemolysate containing different glucose concentrations in the presence of N-ethylmaleinimide at $366 \mathrm{~nm}$

The endogenous reaction rate varied between $\Delta \mathrm{E} / \mathrm{min}$. $=0$ and $\Delta \mathrm{E} / \mathrm{min}$. $=0.0025$ with a mean value of $\Delta \mathrm{E} / \mathrm{min} .=0.00087 \pm 0.00044$.

As the velocity of the overall reaction varied considerably, the 5 -minutes value differed from $-8.6 \%$ to $+11.4 \%$ from the true glucose concentration with a mean error of $3.9 \pm 3.3 \%$. This error is not included in the usual determination of the standard deviation using the same sample.

In the modification described above $\mathrm{N}$-ethylmaleinimide was used to eliminate the endogenous reaction according to a proposal of STORK (3). The reaction usually reached an endpoint after 5-10 minutes (Fig. 2), depending on the glucose concentration. The $\Delta \mathrm{E}$ value should be read

Tab. 2

The stability of the glucose concentration in the hemolysate under various conditions

$10 \mu l$ capillary blood was introduced into $2.0 \mathrm{ml}$ solution 1 prepared without Triton $X 100.0 .005 \mathrm{ml}$ Triton $\times 100$ or $0.1 \mathrm{ml} 3 \mathrm{~g} / 100 \mathrm{ml}$ N-ethylmaleinimide were added as indicated above. At different times $50 \mu l$ were withdrawn twice from this mixture, deproteinized with $0.5 \mathrm{ml}$ perchloric acid and used for glucose determination with an Eppendorf automat 5030

\begin{tabular}{llll}
\hline $\begin{array}{l}\text { Triton } \times-100 \\
\text { N-ethylmaleinimide }\end{array}$ & - & + & + \\
\hline $\begin{array}{c}\text { Hours, after which } \\
\text { samples were taken for }\end{array}$ & & & \\
glucose determination & $\mathrm{mg} / 100 \mathrm{ml}$ glucose $^{2}$ ) & \\
\hline 0 & 49.1 & 49.1 & 48.4 \\
2 & 48.7 & 49.4 & 48.3 \\
18 & 42.4 & 48.8 & 47.8 \\
22 & 40.6 & 49.7 & 48.1 \\
26 & 35.8 & 48.1 & 49.1 \\
\hline
\end{tabular}

3) Mean values from duplicate determinations within a few minutes after the reaction has finished, since a very slow reverse reaction was occasionally observed.

Triton X 100 was added to solution 1 for 3 reasons: It accelerated hemolysis, prevented turbidities and stabilized the glucose concentration in the hemolysate (Table 2).

The addition of the enzyme suspension usually caused an increase of the opticaldensity of $\Delta \mathrm{E}=0.005+0.0019$. This value was determined over 21 days from 3 different

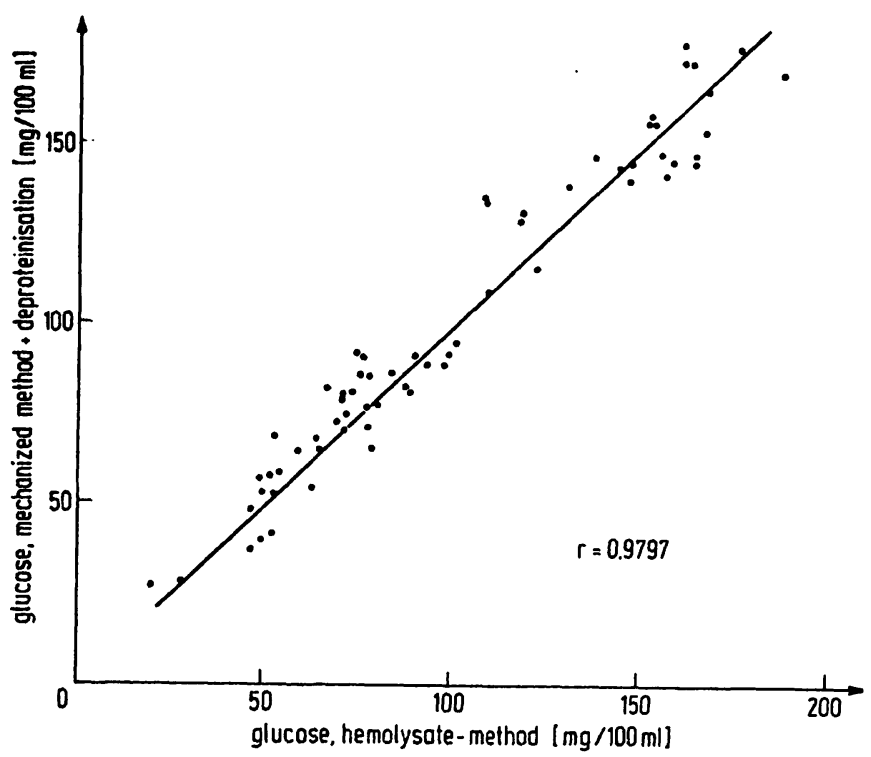

Fig. 3

Comparison of glucose determinations from the same blood sample performed with the autornated and the modified hemolysate procedure
of the hexokinase method

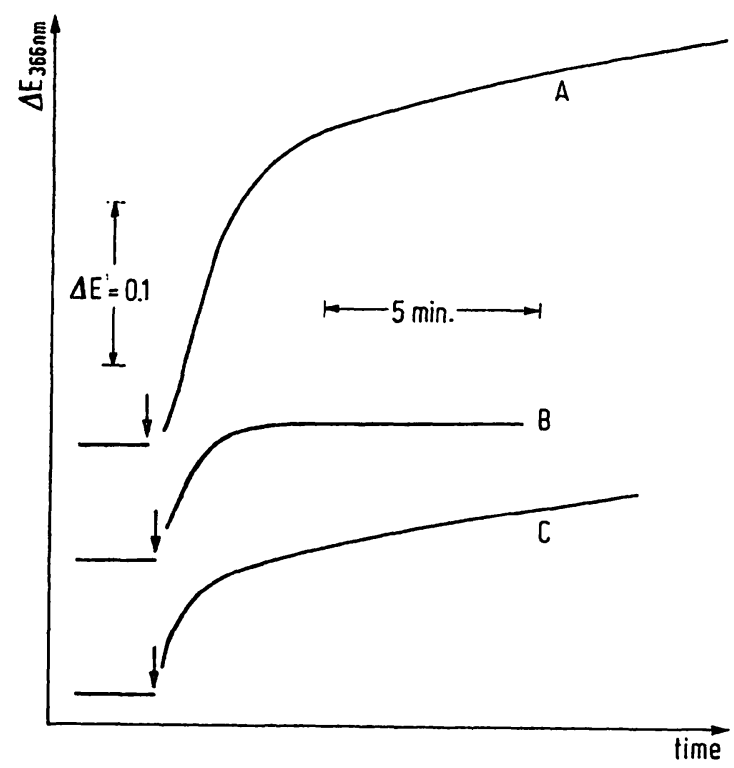

Fig. 4.

The interference of fructose with the glucose determination in hemolyzed blood samples

A) the blood sample was taken from a patient during the infusion of a $5 \mathrm{~b} / 100 \mathrm{ml}$ solution of fructose

B) the blood sample was from the same patient, 48 hours after the last application of fructose

C) this sample was received as described under B, however, $0.01 \mathrm{ml}$ of a $100 \mathrm{mg} / 100 \mathrm{ml}$ fructose solution were added to the assay

The reaction was started by the addition of the enzyme suspension as indicated by arrows 
Biochemica test combinations TC-X-I. For the calculation of the glucose concentration this difference was substracted from the $\Delta \mathrm{E}$-value of the overall assay reaction.

Comparing blood sugar concentrations determined by the automated method with deproteinization and by our modified procedure of the hexokinase method in blood samples from different patients a sufficient correlation was found (Fig. 3).

The only significant interference we have noticed so far, was caused by fructose when infused to patients prior to the capillary puncture. The presence of phosphohexoseisomerase in the hemolysate can introduce the fructose phosphorylated by hexokinase into the glucose6-phosphate dehydrogenase reaction (Fig. 4). The addi- tion of galactose to an assay containing hemolysate did not cause any significant reduction of NADP.

\section{Accuracy}

Control determinations in deproteinized blood samples: coefficient of correlation, $r=0.9797(n=69)$.

\section{Precision}

Labtrol series $(\mathrm{n}=15)$

$\overline{\mathrm{x}} \pm \mathrm{s}=97.3 \pm 1.4 \mathrm{mg} / 100 \mathrm{~m} \mathrm{l}$

coefficient of variation, $\mathrm{CV}=1.5 \%$

Sensitivity

$2.8 \mathrm{mg} / 100 \mathrm{ml}(2 \mathrm{~s})$.

\section{Interference}

Fructose.

\section{References}

1. Stork, H. and F. H. SchMrd, Klin. Wschr. 46, 789 (1968). - 2. HJeLM, M., Z. analyt. Chem. 243, 781 (1968). - 3. Stork, H., personal communication.

Dr. R. Haeckel

3000 Hannover-Kleefeld

Roderburuchstr. 101 